\title{
The Conservation of Kali Pasir Jami' Mosque in Tangerang, Banten
}

\author{
Yulia Nurliani Lukito ${ }^{1}$, Mushab Abdu Asy Syahid ${ }^{2}$
}

\begin{abstract}
The aim of this study is to elaborate the conserving Kali Pasir Jami' Mosque in Tangerang City, Banten Province that includes the participation of local communities. There is an initial conservation program proposed by the local government but it is not yet clear of how should the collaboration between communities who have done practical conservation and local government who slowly plans the conservation program. The lack of historical documentation of the building and unstructured research done by communities imply a potential threat to the conservation effort and loss of historical values of the mosque. This paper is the result of both qualitative and quantitative approaches such as observation and in-depth interviews in analyzing the conservation of the mosque. The finding of the research shows the important role of local communities in the sustainability of the mosque although there is also an urge to involve experts and government to create the right strategy in conserving the mosque.
\end{abstract}

Keywords — conservation, Kali Pasir Jami’ Mosque, preservation

\section{INTRODUCTION}

$\mathbf{H}^{2}$ eritage buildings that are sympathetically preserved can give long term benefits for communities that value them. Involving communities means that those heritage buildings are continuously being appreciated and the environmental, social and economic costs for the heritage buildings are relatively low. When done well, preservation and adaptive reuse can maintain the heritage significance of a building and help to ensure its survival. A historic building has architectural, aesthetic, social values and even becomes a symbol of identity and a part of heritage. [1] A debate as whether to preserve as found or rebuild building heritages with new construction has been a never-ending issue in conservation. [2] Certainly, there is a need to preserve historical buildings that symbolize the communities who created and lived in the surrounding area. However, preserving and conserving buildings without concerning current needs and social dynamic as well as involving experts will threaten sustainability of the historical buildings.

The aim of this paper is to discuss the process of conserving Kali Pasir Jami Mosque in Tangerang City, Banten Province that includes the participation of communities in the area surrounding the mosque. The idea of preserving and conserving the mosque concerns not only historical and cultural values but also dynamic social and cultural changes. We want to argue that since there is a lack of documentation and preparation process, there is no clear direction of how the conservation program should be conducted. Communities living around the area of Kali Pasir
Jami' Mosque have already conducted limited maintenance while local government gives attention recently plan to do the conservation program. There should be a good collaboration between communities and local government and a more progressive vision on how the architecture of the mosque can be creatively and meaningfully interpreted for the conservation program.

Conservation of historical buildings should be interpreted more than the physical continuity of historic structures and also the continuity of non-material aspects of culture. [3] Previously, the conservation of mosque architecture is strongly related to Western concepts and differences between Islam and West (or secular approaches) in perceiving architectural objects values. In relation to architecture, mosques buildings are not necessarily based on functionality aspects - which somewhat only support the prayer's practice. The architectural conservation can be discussed by how the facilities provide the function of space but what kind of representation that the building has. During the early Islamic development era, the first mosques were built by minimum resources, simple design and technology but had education, health, socio-political functions. Therefore, considering intangible aspects of mosque, especially the relation of the mosque with its surroundings, is very important. [4]

Philosophical and ethical considerations are important parameters of architectural conservation. Preserving religious buildings include political, economic, cultural and physical factors because the buildings express religious and cultural values to local communities. In the nineteenth century, an art critic John Ruskin asserted for cultural continuity and the notion of maintenance as an ongoing process and did not agree with a restoration. [5] A French architect EugèneEmmanuel Viollet-le-Duc proposed restoration as a way to re-establish a historic building and providing us an understanding of history and place. [6] In the development of the study of conservation, an Austrian art historian Alois Reigl defined memorial values, which deal with age and history, and present-day values such as usefulness and artistic value. Decision how to conserve heritage buildings should consider these different values. [7]

Defining heritage buildings in post-World War II includes natural, indigenous and the orientation to historic place, which will significantly affect the people living in the surrounding areas and their culture. [8] A more recent scholar mentions that heritage values are determined by contexts more than personal hegemonic or a priori taste. [9]

${ }^{1}$ Department of Architecture, Faculty of Engineering, Universitas Indonesia, Kampus UI Depok, West Java, Indonesia.

${ }^{2}$ Department of Architecture, Faculty of Engineering, Universitas Indonesia, Kampus UI Depok, West Java, Indonesia.

*Correspondence to T. Author, email: yulia@ui.ac.id Tel.:+62-721704947; fax.:+62-721-704948. 
In the preservation and conservation of mosques, one must also add the values of religion and culture beside the historical and the dynamic aspects of the mosques, the communities and the religion. As a risk in doing conservation is to have destruction instead of fixing damage, especially when the subjects who conduct the conservation project lack of practical craftsmanship. The lack of historical building documentation by community implies practical craftsmanship maintenance that potentially threatens its historical values too.

Historical building conservation often engages a perspective contestation between involving agents beside its physical attributes to value the authenticity and cultural importance inside. This issue is also related to memory and tradition, where architectural elements allow to build an identity of community and city. Christine Boyer highlights the collective memory during conservation that is potentially debatable, contestable or transformable within the memories [10] and the need for an awareness that most of the preservation action is a commercial project and this somehow opposes the main function of building. Mosque architecture can also be read as a collective memory, therefore in conserving mosque architecture one must question what should be changed or not to be changed by investigating collective memory. Investigating those non-physical attributes becomes a tool to uncover symbols, icons and archives connected within memories.

Thus, the role of regulative institution in selecting and managing monument are also inevitably co-related with commodification symptom on heritage objects as capital investment in urban or city space. Here, a historical mosque is seen instead as a objectified modern monument, as both product of modernization and collective memory, and does not oppose to the idea of modern progress itself. This sounds coherently with Mitchell's quote in Rajagopalan's writing about modern state's consciousness regarding the preservation action, that is, "One of the odd things about the arrival of the era of the modern nation-state was that for a state to prove that it was modern, it helped if it could also prove that it was ancient". [9]

\section{KALI PASIR JAMI’ MOSQUE IN TANGERANG CITY}

The site of Kali Pasir Jami' Mosque is located on Jalan Kali Pasir Indah, RT 02/RW 04 No. 18, Sukasari district or known as the 'Old Market' complex of Tangerang City. This area is also known as one of places where Cina Benteng community (half Chinese, half native Indonesian) have been lived since the 15 th century. [11] The area of the site consists of dense local settlements and some old Chinese buildings. The location of Kali Pasir Mosque is also near Boen Tek Bio, a historic Chinese local shrine. The mosque is also located near the Cisadane River and has an old cemetery complex in front of the mosque. Passage ways around Kali Pasir Jami' Mosque are very narrow and could only be passed maximum three to four people walking side-by-side. The mosque and the shrine are often mentioned by local people and government as become symbols of religious and cultural tolerance for being built close to each other and making diverse patterns and cultures in the main central of Tangerang since the early period of the development. [12]

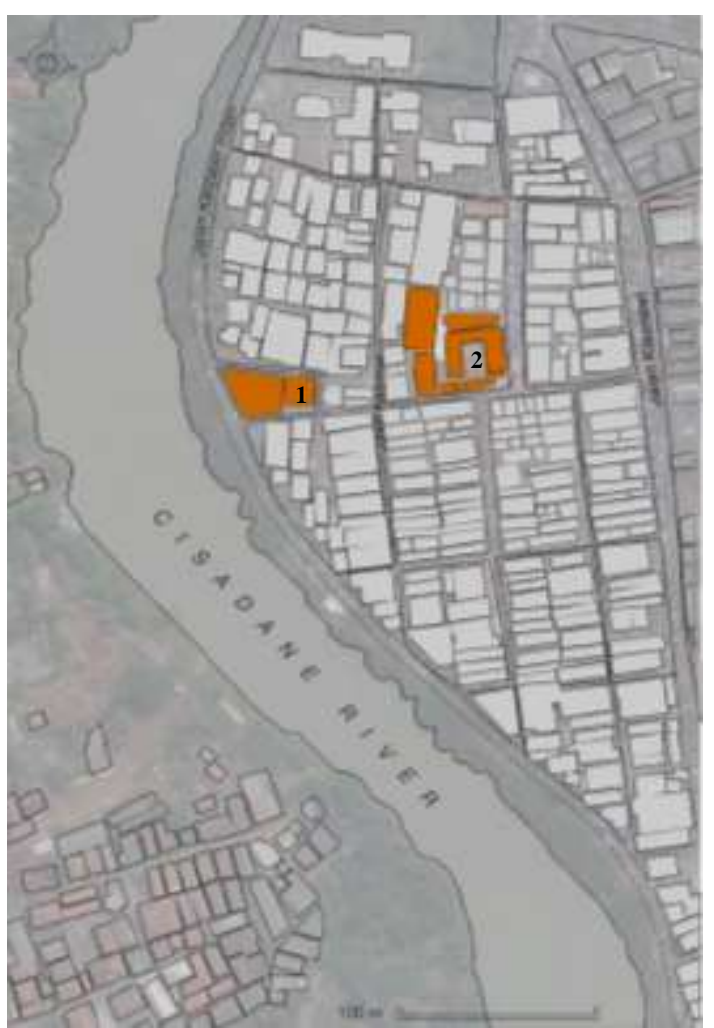

Fig 1. The site of Kali Pasir region and 'Old Market' of Tangerang: 1) Kali Pasir Jami' Mosque complex and 2) Boen Tek Bio shrine, as traced and edited from Google Earth, 2016.

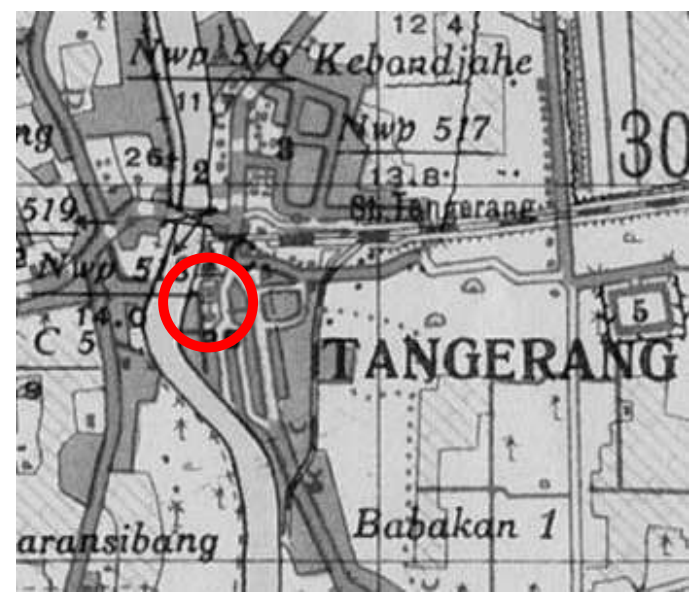

Fig 2. The map of Old Market of Tangerang city drawn by Dutch-Indies colony, published in 1915-1942. In the map, the location of Kali Pasir Jami' Mosque with the symbol $\Psi$ and Boen Tek Bio shows that both buildings also became the main central of the city [13], where local community were living nearby city station, surrounding rice fields and forest (source: Topographische dienst, 05120-038-C, Royal Tropical Institute).

The government of Tangerang city has legally given the mosque and the shrine as two of the nine historical buildings in Tangerang, which was written in Surat Keputusan Walikota Tangerang No. 430 / KEP. 337 - DISPORBUDPAR / 2011 on August 2011. [14] However, there is no comprehensive records and documentation of the history of Kali Pasir Jami' Mosque neither how it was built and changed from time to time, except from Hajj Sjairodji - the head of Dewan Kesejahteraan Masjid (DKM or the management of the mosque). Hajj Sjairodji heard the history of the mosque verbally from his predecessor - his grandfather. 


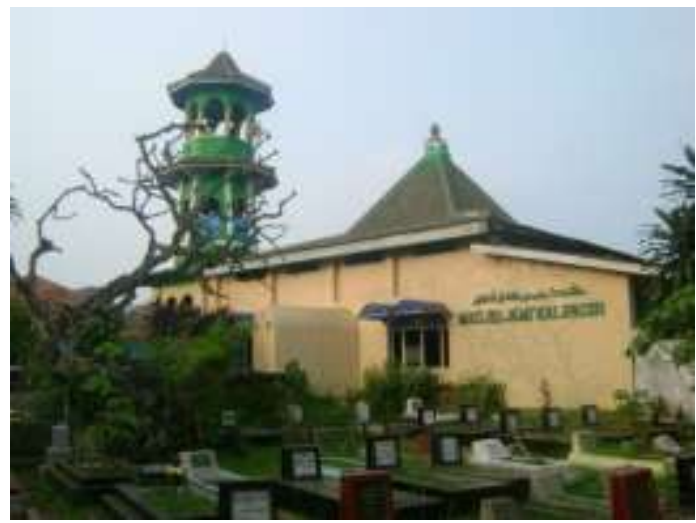

Fig. 3. Kali Pasir Jami' Mosque, its Minaret and the cemetery complex. (source: Public domain)

During the early period, the Cisadane River was known as the third merchantry transit stream after Sunda Kelapa (Batavia) and Banten. In 1608, Raden Surapura Wirasutadilaga as the Kahuripan Prince went to Kali Pasir region from Bogor and built an initial small mosque. While living there, he used local building materials such as palm leaves and trunks. The place was also known as 'petilasan' or the remain of the past of Ki Tengger Djati's, a famous ascetic who previously stayed there before it was reopened by the Prince. It was also said that Islamic scholars (ulama') used to build prayer space near to a river in order to use the water for the water source for ablution. In the next generation, approximately between 1687-1700s, the grandson of the Kahuripan Prince, Tumenggung Pamit Wijaya, then built the mosque so that it became wider and sturdier by erecting four wooden permanent columns and without any wall structure.

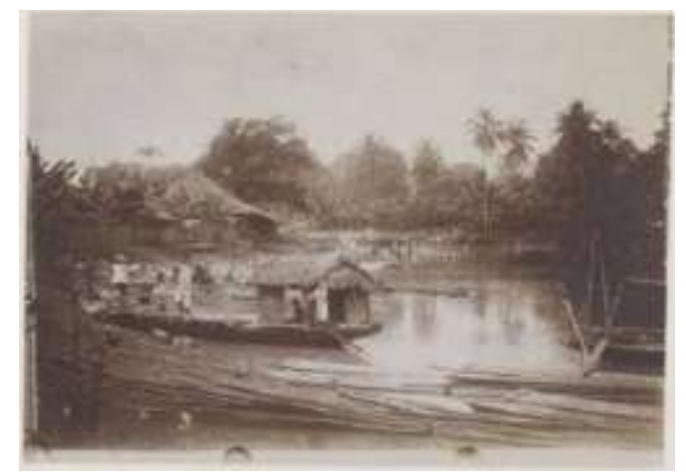

Fig 4. Veerpont over de Kali Pasir te Batavia in 1910s (source: KITLV Online Media).

In 1712-1740, Pamit Wijaya gave the throne to his son, Raden Bagus Uning Wiradilaga. The next leader was Tumenggung Aria Ramdhon and the inheritance to preserve the mosque continued. According to Hajj Sjairodji's research, the title of "Aria" was also mentioned in the Dutch East Indies Company (VOC) archive, Dagh Register 4, March 1680, which explained an order to Aria Sutadilaga I - VII to become Bupati and rule some of Banten region until 1809. In 1780s-1823, Aria Tumenggung Sutadilaga, the son of Aria Ramdhon died and replaced by Raden Aria Idardilaga as the last "Aria" bloodline lived in Tangerang in 1830. The maintenance of the mosque was continued by Nyai Raden Djamrut and Raden Abdullah during 1865-1904s. [15]

Hajj Sjairodji was convinced that the first overhaul of Kali Pasir Jami' Mosque was done by Hajj Abdul Kadir Banjar, Hajj Muhibi and Muhidi during 1904-1918. The wooden mosque was being renovated and the walls were made by bricks and the minaret was also built. It was the first phase of building the minaret led by Raden Jasin Judanegara. The next renovation was done by Hajj Mohammad Toha (the son of Hajj Muhibi), Hasbullah Kadir, Nyai Guru Murtafiah, and H. M. Badri in 1959-1961. Some of these family names can be traced from the mosque's cemetery gravestones. Some of the anchestors of Kahuripan king were buried there, such as Tumenggung Aria Ramdhon, Nyai Guru Murtafiah, and also Raden Ahmad Penna, who became the first Bupati of Tangerang Regency. In 2000, the minaret was rebuilt again led by Hajj Sjairodji and the repainting of the mosque complex was done during 2011-2016 (See Fig. 9) after a new legal status of the mosque as listed building. But still, the money for the renovation was collected from charitable funds from local people.

Aside from the description above, some people believe that the mosque's minaret followed Chinese pagoda's roof, even the decorative ornamentation of mosque (See Fig. $9 \&$ Fig. 14) to say that Chinese culture influenced the mosque design. On contrary, Hajj Sjairodji explained that the myth about how the shape of minaret associated to Chinese pagoda was not true, even though this myth was well known and spread. The local community preferred to conserve Kali Pasir Mosque as it is and maintain the mosque as a center for community. A ceremony of 'Arakan Perahu' that is held annually to celebrate Maulid or the birth of prophet Muhammad also becomes the intangible aspect that creating strong sense of belonging to the muslim local community. This infers how the symbolical and functional values precede the historical and architectural values of the mosque. [16]

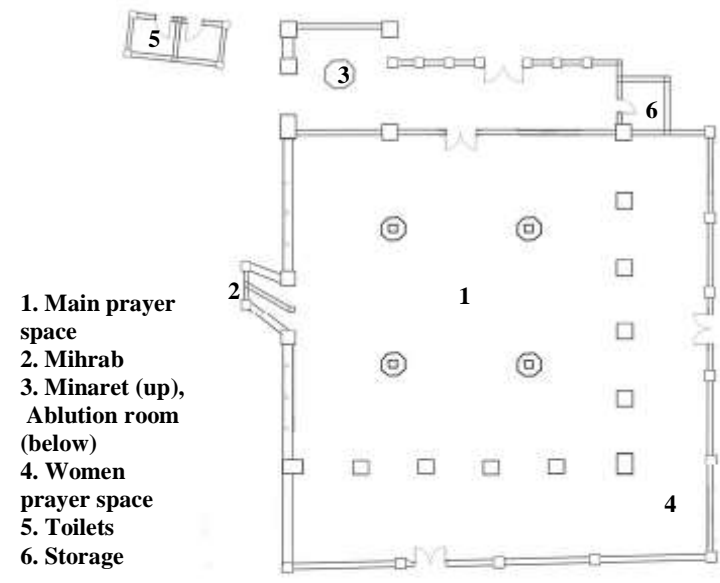

Fig 5. Plan of Kali Pasir Mosque revised version (source: Feby Hendola)

Since the mosque became a listed building, the management of the mosque (Dewan Kemakmuran Masjid or DKM) did a research to find written history of Kali Pasir Mosque. One of DKM members once visited Sultanate in Cirebon and did a research on the origin of traditional mosque and building of the fifteenth century Java and wanted compare the results with Kali Pasir Jami' Mosque. Additionally, DKM management also wrote an article writing which is titled "Nyukcruk Galur Mapay Patilasan: Masjid Jami Kali Pasir" that narrated the mosque's history using their own impressions and recalling the past by their own words. The phrase came from Sundanese which means tracing places where relate to mosque history. It includes history of Islam spread in Tangerang as well as raising of Islamic Pasundan sultanate, history of DKM management, mosque 
descriptions, ethnicity and so on. This bulletin was published limited. Most of the resources used to do the study come from limited collection of the Dutch East Indies administrative archives on Tangerang city and Java as well.

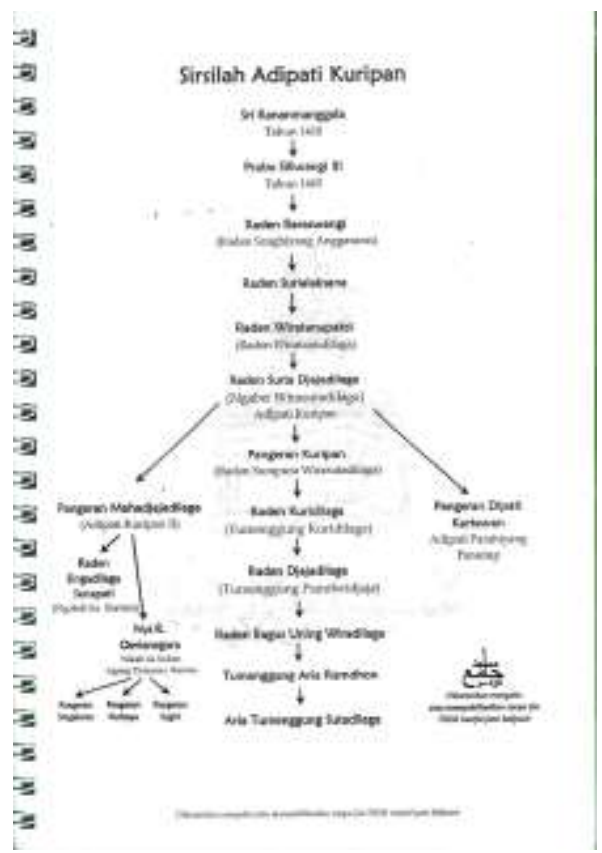

Fig 6. A page of Nyukcruk Galur Mapay Patilasan: Masjid Jami Kali Pasir bulletin showing the family tree of Kahuripan Prince (Adipati) who related to the mosque welfare management time by time. (source: Hajj Sjairodji)

\section{SOME EFforts to CONSERVE KALI PASIR JAMI' Mosque}

Kali Pasir Jami' Mosque becomes first mosque in Tangerang that represents Islamic culture and local muslim community's daily lives in Old Market complex. The architecture of Kali Pasir Jami' Mosque is a typical of local buildings in Tangerang despite its functions as a prayer room and a community center. People who first built this mosque arguably had no intention to build a monument that caused the building as having a common architectural style. For Muslim communities in the surrounding areas, they can trace the relation of architectural elements to their everyday architecture such as the four main posts or soko guru found in Javanese house. The mosque's roof and the crown (mustaka) is also a common roof found in many parts of Indonesia and the wooden materials can be found easily in Java. As a regular maintenance the committee of the mosque paint the mosque regularly and it is also possible to add decorations. In line with the function of the mosque and the importance of the mosque for the communities, having a drastic change in function in the conservation seems to be unnecessary.

The DKM at least considered four architectural elements which are arguably as the most original in mosque complex: 1) old cemetery complex, 2) soko guru, 3) mustaka or crown, and 4) mimbar facing Mecca.

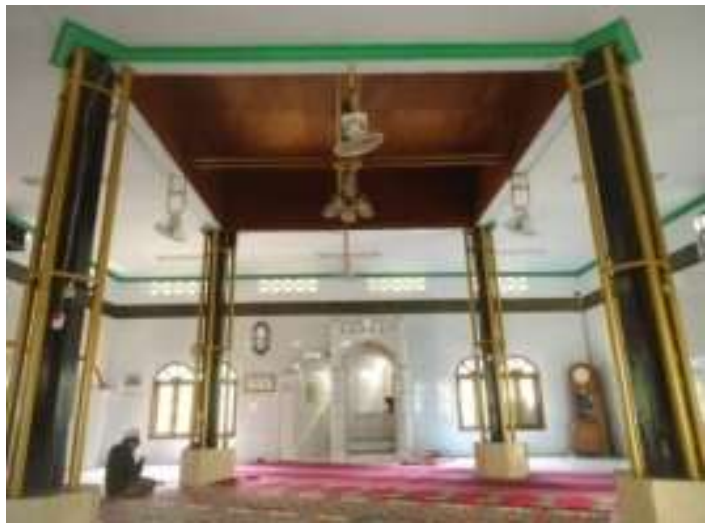

Fig. 7. The interior of Kali Pasir Jami Mosque and the four main posts or soko guru. (source: Author's collection).

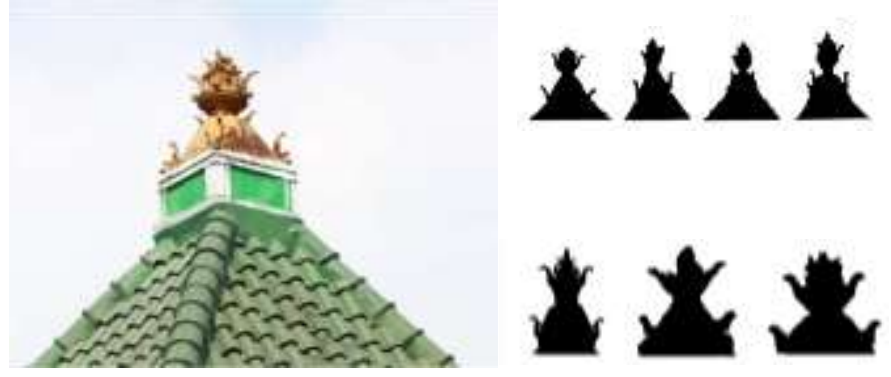

Fig 8. The crown (cungkup or mustaka) as the oldest architectural element of Kali Pasir Jami' Mosque (left), which resembles some of mustaka types (right) where are often found in traditional mosques in Cirebon [17] (source: Public domain)

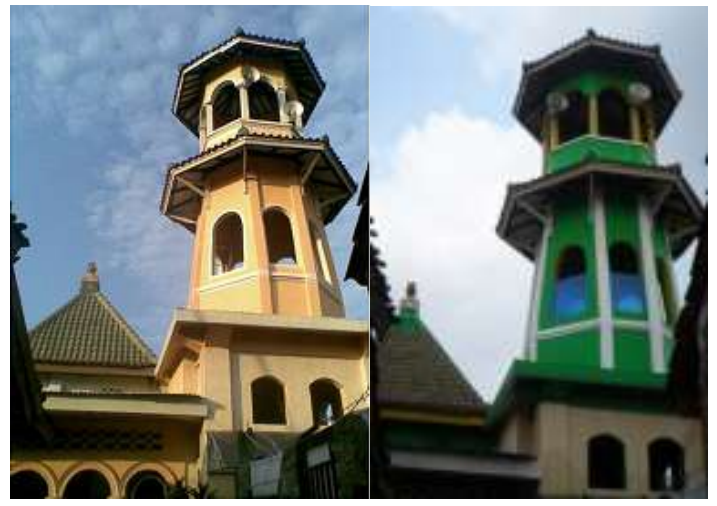

Fig. 9. The minaret of Kali Pasir Jami Mosque before and after repainted during 2011-2016 (source: Author's collection).

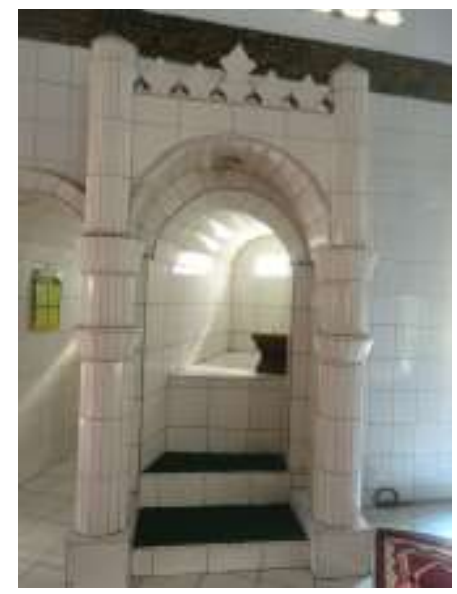

Fig. 10. 'Mihrab' facing towards Mecca with ceramic ornaments. The mihrab, interior walls and floors are built mostly by white ceramic material (source: Author's collection). 
The DKM management skeptically accepts the formal status of mosque as a listed building and the conservation program that will be given. They hesitate to open the mosque for tourism -as unavoidable consequences of listed buildings. They are quite confidence that local communities will help the mosque to sustain because so far the maintenance of the building has been done even before the government gives a new legal status for the mosque. There is a different perception between the DKM management that represent local communities and local government in determining the future of this historical building. DKM management wants to focus on programs that directly affect users or jamaah (congregation) such as the physical aspects of the mosque and the regular programs and activities to serve communities. With the lack of funds and resources, the mosque has some decays and deteriorations. The management have only regular maintenance plan to prevent decay and fix the building such as painting the walls and changing the roof tiles.

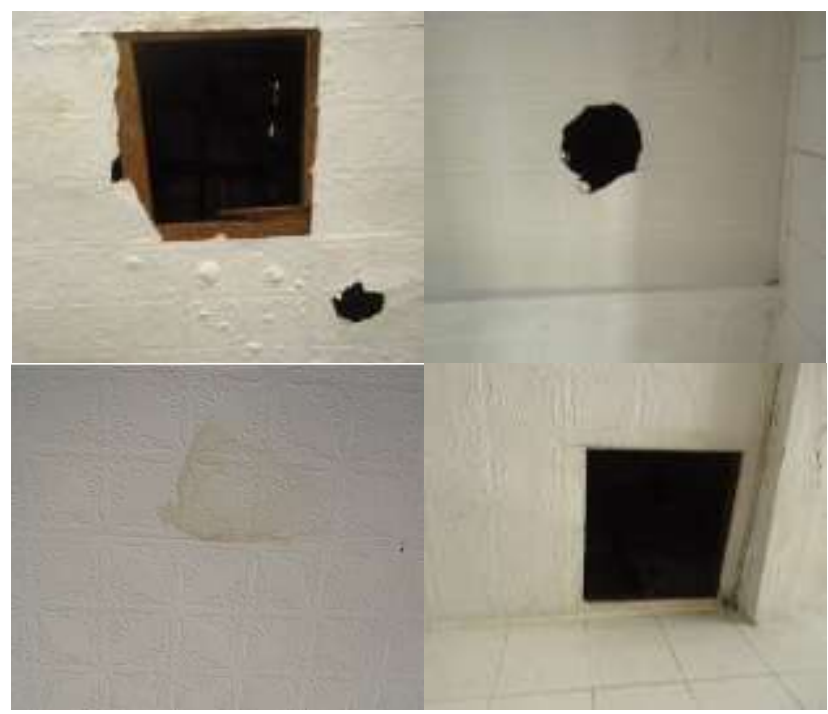

Fig. 11. Some cases of building deterioration (source: Author's collection).

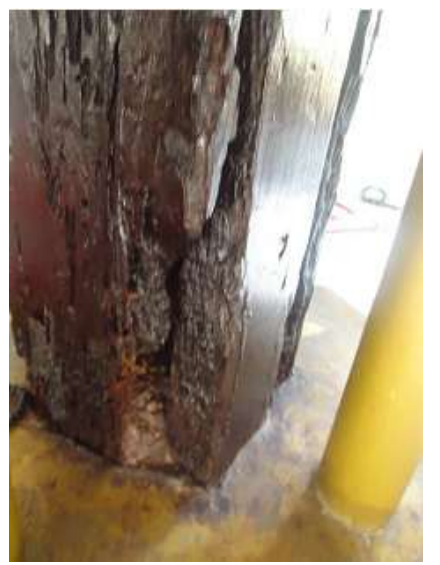

Fig. 12. Decay of wooden soko guru which is supported by stainless stee column (source: Author's collection).

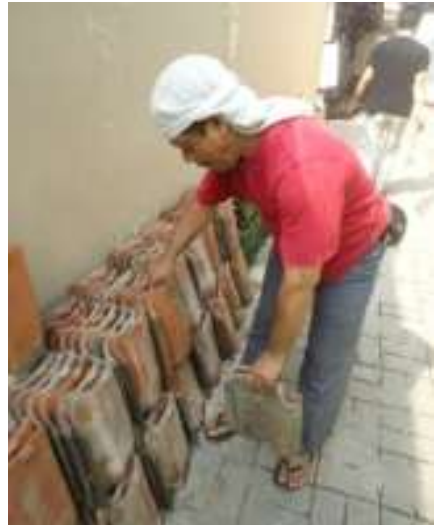

Fig 13. The work of changing roof tiles by local community in May, 2016 (source: Author's collection).

Selecting the priority of architectural preservation and conservation is related in how the community perceive the building elements as their collective memory output. As it is built on the diverse urban characteristic site, this similar issue inevitably emerges to Kali Pasir Jami' Mosque too. Thus, the mosque can also be read as a collective memory fragments of community in Kali Pasir and Old Market - DKM management, muslim local community, even Chinese or nonmuslim ones may reciprocally involve. [18] Therefore, it is important to consider the memory investigation in mosque's history so that the problem of each element's origin can be well explained. Competing the status and the authority of conservation between involving agencies with different memory is another challenging phase after. [19]

According to the latest in-depth interview result with DKM management secretary of Kali Pasir Jami' Mosque, there was a meeting between the DKM management of the mosque and the government of Tangerang city in order to discuss the future of the mosque in February, 2016. The government also propose a plan to implement adaptive reuse so that the mosque can better function especially in relation to its status as a listed building and its function as a community center. However, there is not enough discussion on the strategy and the implementation and the role of local community in the conservation program. Considering that local communities have helped to preserve the mosque, the collaboration between the government and local communities will ensure the sustainability of the mosque. Moreover, there is an urge to have experts in history, architecture and preservation in order to assist the conservation process.

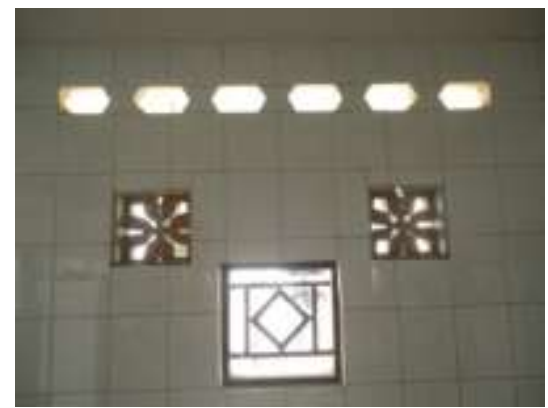

Fig. 14. Decorative elements on the wall (source: Author's collection). 


\section{CONCLUSION}

The early process of conserving Kali Pasir Mosque in Tangerang City, Banten Province shows the involvement of local communities. There is an initial conservation program proposed by the local government but communities living in the area near the mosque have done practical conservation. There is not enough historical documentation nor historical evidence of the mosque and this condition may give a potential threat to the preservation and the sustainability of the mosque. Both local communities and the government play an important role in conserving the mosque, although there is also an urge to involve experts in order to have the right strategy in the conservation of the mosque.

\section{REFERENCES}

[1] B. M. Feilden, Conservation of Historic Building. London: Butterworth Scientific, 1994, pp. $1-22$.

[2] A. Orbasli, Architectural Conservation. Singapore: Blackwell Publishing, 2008.

[3] H. U. Khan, "Architectural conservation of the mosque", The Newsletter, No.57, 2011, pp. 22-23.

[4] N. Stanley, "Cultural heritage in postwar recovery," ICRROM Coservation Studies \#06, Rome, Italy, 2007.

[5] J. Ruskin, The Seven Lamps of Architecture, New York: Dover Publication, 1989, p. 194.

[6] E. Viollet-le-Duc, The foundations of architecture, New York: George Brazille, 1990, p. 195.

[7] K. W. Forster and D. Ghirardo, "The modern cult of monuments: its character and origin," in Oppositions 25, 1982, pp. 21-50.

[8] M. Truscott \& D. Young, "Revising the Burra Charter: Australia ICOMOS updates its guidelines for conservation practice," in
Conservation and Management of Archaeological Sites, Vol. 4, 2000, pp. 101-116.

[9] M. Rajagopalan, "Preservation and modernity: Competing pespectives, contested histories and the question of authenticity," in The SAGE Handbook of Architectural Theory, S. Cairns, G. Crysler, H. Heynen, Eds. London, California, New Delhi and Singapore: SAGE Publications, 2012, pp. $308-24$.

[10] M. C. Boyer, "Collective memory under siege: The case of heritage terrorism', in The SAGE Handbook of Architectural Theory, S. Cairns, G. Crysler, H. Heynen, Eds. London, California, New Delhi and Singapore: SAGE Publications, 2012, pp. 325 - 38 .

[11] D. Ramsay. (2011, May). An encounter with history in Tangerang. Available: http://www.thejakartapost.com/news/2011/05/16/anencounter- with-history-tangerang.html

[12] FB. Kaluara \& AJ. Priyadi, "Masjid jami Kali Pasir: in between myth and a need for historical accuracy," International Journal on Heritage Architecture, Vol. 1, No. 3 2016, pp. 355-364.

[13] Pemerintah Daerah Kota Tangerang. (2007, August). Asal muasal masyarakat Tangerang. Available: http://www.tangerangkota.go.id/ asal-muasal-masyarakat-tangerang

[14] Anon. (2015). Masjid dan makam kali pasir Tangerang. Balai Pelestarian Cagar Budaya Serang. [Online]. Available: http://kebudayaan.kemdikbud.go.id/bpcbserang/2015/09/01/masjid-danmakam-Kali Pasir-tangerang/

[15] DKM Kali Pasir Tangerang. Nyukruk Galur Mapay Patilasan Masjid Jami Kali Pasir, Tangerang, 2016.

[16] B. T. Susanti, "Conserving religious heritage through people-involved management: The case of mosques and chinese temples in the urban coastal area of Java, Indonesia," Ph.D. dissertation, University of Bath, 2013.

[17] Y. A. Nugroho, "Mustaka pada bangunan islam kuna di Cirebon" S.Ars S. Hum. thesis, Dept. Archaeology, Hum., Universitas Indonesia, Depok, WJ, 2012.

[18] Benteng Heritage Community. (2014, July). Available: http://www.bentengheritage.com/site/

[19] F. Diez, "Chapter 15, Heritage," in The SAGE Handbook of Architectural Theory, S. Cairns, G. Crysler, H. Heynen, Eds. London, California, New Delhi and Singapore: SAGE Publications, 2012, pp. 274-286. 